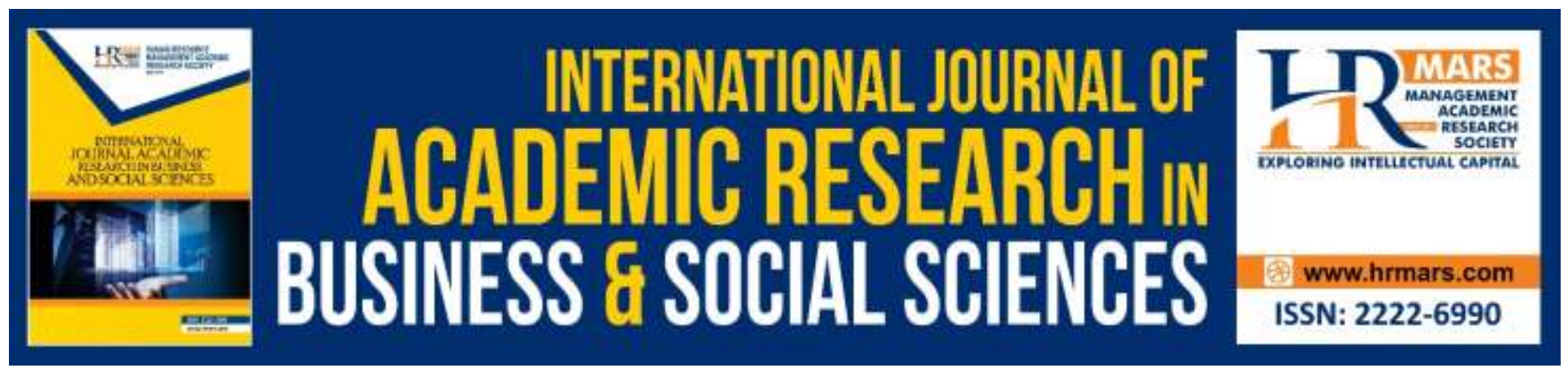

\title{
Evaluation of Highly Immersive Program (HIP) Using CIPP Model
}

\section{Vivienne Rozanna Matthew \& Hamidah Yamat}

To Link this Article: http://dx.doi.org/10.6007/IJARBSS/v10-i4/7152

DOI:10.6007/IJARBSS/v10-i4/7152

Received: 26 February 2020, Revised: 22 March 2020, Accepted: 28 March 2020

Published Online: 19 April 2020

In-Text Citation: (Matthew \& Yamat, 2020)

To Cite this Article: Matthew, V. R., \& Yamat, H. (2020). Evaluation of Highly Immersive Program (HIP) Using CIPP Model. International Journal of Academic Research in Business and Social Sciences, 10(4), 509-526.

Copyright: (c) 2020 The Author(s)

Published by Human Resource Management Academic Research Society (www.hrmars.com)

This article is published under the Creative Commons Attribution (CC BY 4.0) license. Anyone may reproduce, distribute, translate and create derivative works of this article (for both commercial and non-commercial purposes), subject to full attribution to the original publication and authors. The full terms of this license may be seen

at: http://creativecommons.org/licences/by/4.0/legalcode

\section{Vol. 10, No. 4, 2020, Pg. 509 - 526}

Full Terms \& Conditions of access and use can be found at http://hrmars.com/index.php/pages/detail/publication-ethics 


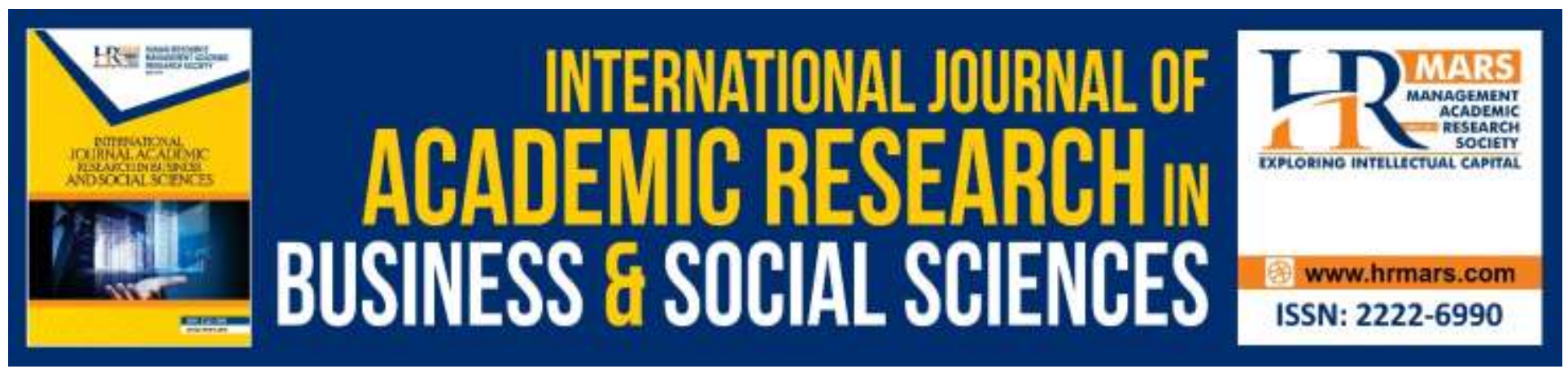

\title{
Evaluation of Highly Immersive Program (HIP) Using CIPP Model
}

\author{
Vivienne Rozanna Matthew \& Hamidah Yamat \\ Fakulti Pendidikan, Universiti Kebangsaan Malaysia \\ E-mail: vie.rozanna@gmail.com, hamidah_yamat@ukm.edu.my
}

\begin{abstract}
Education in Malaysia aims to produce holistic and competitive individuals to meet the needs of $21^{\text {st }}$ century. As the demand of globalized economy increasing, English language serves as the international language and is very important to support the growing economy. Highly Immersive Program (HIP) has been introduced since 2016 by the Malaysia's Ministry of Education to improve the strategy established under the policy of "Upholding the Malay Language and Strengthening the English Language". This study aimed to evaluate the Highly Immersive Program whereby CIPP (context, input, process and product) model of evaluation is employed. This evaluation has highlighted that the HIP needs more support from the community and teachers. A total of 261 participants consists of a School Head, 52 teachers, 104 students and 104 parents and community participated in this study. The data obtained were analysed through descriptive statistics and to determine the significant differences among students, a paired sample $T$ test was employed. The results of the study revealed more improvements were required from students and parents and community as well as the teachers to ensure the effectiveness of the Program.
\end{abstract}

Keywords: Highly Immersive Program, Immersiveness, CIPP Model, Evaluation

\section{Introduction}

English language has been included as a compulsory subject in the national education curriculum of Malaysia and it is guided by the education policy. It was since 1957, the status of the English language was institutionalized as an important second language in the Education Ordinance and being reiterated in the Education Act 1996 (Government of Malaysia, 1996). Not long after that in 1970, the National Education Policy was issued (Ministry of Education Malaysia, 2012). Through the introduction and implementation of several key policies, The Ministry of Education has long conceded the importance of improving the quality of English proficiency amongst students as well as teachers. Afterward in 2012, according to Ministry of Education Malaysia(2013), the new Malaysian Education Blueprint was developed after an extensive review of the national education system was conducted in the year before. 


\section{Background of the Study}

The English Highly Immersive Program (HIP) was introduced in 2016 by the Ministry of Education with the objectives to develop highly immersive English language environment in schools to support English language learning and encourage students' participation in related school activities. Moreover, the purpose of this Program also to increase student proficiency in the English language in and outside of classroom. In line with the education policies in Malaysia, the Highly Immersive Program was introduced and implemented in every public secondary and primary schools in Malaysia. The formal learning of English must be supported by a highly immersive English-rich environment. However, this Program just entered the third year of its implementation and yet it seems vague. The case is some schools witness poor participation of non-English implementation of Highly Immersive Program (HIP). Most of the activities are mainly conducted by the English language teachers in the school.

\section{Problem Statement}

This study presents an evaluation on the implementation of the HIP in a semi-urban school in Bintulu, Sarawak. To date, there are 9865 schools in Malaysia participating and implementing HIP and SK Kampung Baru, Bintulu is one of them. This study was conducted throughout the semesters of schooling session of year 2019 with the selected participants from Primary 5, the school head, teachers, last but not least, the parents and community. Mostly the students are native speakers of Iban language and Melanau language. Currently, there is no proper guideline on how to implement in the Highly Immersive Program and yet schools are implementing. Therefore, there is a need to evaluate the Program as currently there is still no evaluation measures conducted. Thus, the study will also explore how the evaluation can be used to assess how effective is the HIP?

Therefore, CIPP Model used to evaluate the Program. CIPP model is an evaluation model for curriculum evaluation given by Stufflebeam in 1983 which includes four elements: C- Context, I-Input, P-Process and P-Product. To evaluate the quality of the Program at school, this model can be used effectively.

\section{Purpose of Study}

This study intends to gauge the implementation of HIP in a primary school in Bintulu, Sarawak.

\section{Research Questions}

The corresponding research questions are:

1. How relevant were the Program contents of HIP?

2. How effective were the HIP in school?

3. What is the process of HIP?

4. What is the product of HIP?

\section{Significance of the Study}

For the case of this research, the significance is targeted to the teachers, school leader also known as the school administrators, parents and community, and the policy planners.

\section{Teacher}

The findings of this study will benefit the teachers to increase range of teaching strategies which help to accommodate to different learners. It is hope that the Program will eventually improve the 
INTERNATIONAL JOURNAL OF ACADEMIC RESEARCH IN BUSINESS AND SOCIAL SCIENCES

Vol. 10, No. 4, April, 2020, E-ISSN: 2222-6990 @ 2020 HRMARS

students' English proficiency. Teachers will also be able to use the available resources to the maximum to provide a fun and meaningful learning in the classroom.

\section{School Head}

This study will demonstrate the evaluation model can be useful to School Head to gain insights and apply approaches recommended in HIP. From the evaluation, school leader or school administrators will be able to teach students better.

\section{Parents and Community}

Through the findings, parents and community will be able to provide awareness to others on the importance of the Program to the students and school. Hence, once they have the awareness, they could give their full support towards the Program. Parents can contribute by having the community to provide their expertise and assistance for the school.

\section{Policy Planner}

From the evaluation of the HIP, it can be a beneficial tool for the policy planners to recognize the challenges that the teachers had in implementing the Program. By evaluating the Program, policy planners will know how to develop the Program and identify what policy needs to be carried out or changes needed to the existing policy.

\section{Operational Definition}

\section{Evaluation}

Stufflebeam (2003) stated that evaluation is the process of defining, obtaining, providing, and applying descriptive and judgmental information about the merit and worth of some object's goals, design, implementation, and outcomes to guide improvement decisions, provide accountability reports, inform institutionalization or dissemination decisions, and improve understanding of the involved phenomena. Ornstein \& Hunkins (1998) stated that evaluation is a process we carry out to acquire data to determine whether to make any changes, to make adjustments in order to improve, eliminations or accept something in the curriculum. Brown (1989) believed that continuous evaluation is important as there should always be preparation for revision of all of the elements in the syllabus planning. As for Karmel and Karmel (1978), they defined evaluation as a constant and comprehensive process which involves judgment that includes all aspects of quality of education. It is important to focus on the aspect of education's quality evaluation. As the number of educational institutions and schools increasing, there is a need to put more attention on the evaluation of quality of education since it is responsible for shaping the individuals and society in the long run.

\section{Highly Immersive Program}

Under the MBMMBI policy, this Program was introduced to improve students' proficiency in English language. Through an intense exposure to English, it aims to instil positive behaviours in using and learning English language. HIP supports five shifts of MEB and aligned with student aspirations highlighted in the Malaysia Education Blueprint (MEB) 2013-2025. The five shifts of the MEB are as follows:

1. Provide equal access to global standard of qualified education.

2. Ensure every child to learn additional language and competent in Bahasa Malaysia and English Language. 
INTERNATIONAL JOURNAL OF ACADEMIC RESEARCH IN BUSINESS AND SOCIAL SCIENCES

Vol. 10, No. 4, April, 2020, E-ISSN: 2222-6990 @ 2020 HRMARS

3. To inculcate good values in Malaysian.

4. Establish parents, community and private partnerships.

5. Enabling JPNs, PPDs and schools to tailor alternatives to their requirements.

\section{Primary School}

Primary school is identified as a school for children between the ages of seven and twelve to register and enrol in the facility for their primary education. The primary school term starts in January and ends in November.

\section{Literature Review}

\section{Theoretical Framework}

In this study, the Acquisition-Learning hypothesis is implemented in as an inclusion of the theoretical framework. Krashen (1988) referred that here are two autonomous second-language performance systems, 'the acquired system' and 'the learned system'. The 'acquired scheme' or 'acquisition' is the result of a very comparable subconscious process when kids obtain their first language. It needs significant interaction in the target language which is a natural communication where the speaker focuses in the communicative act and not in the form of their utterances.

\section{Second Language Acquisition (SLA)}

The Stephen Krashen's theory of Second Language Acquisition (SLA) consists of five hypotheses which are the Acquisition-Learning hypothesis, the Monitor hypothesis, the Input hypothesis, the Natural Order hypothesis and the Affective Filter hypothesis. The prime focus of this theory is that a person has the ability to acquire a second language as acquiring his or her mother tongue. The theory disregards the use of extensive use of grammatical rules or structure of language but rather depends on the input received by the learner (Raju \& Joshith, 2018).

Krashen (1982) stated that a person has two distinct and independent ways of developing competence in a second language, hence the theory of the Acquisition-Learning hypothesis. It is mainly through two processes which are 'acquisition' and 'learning'. The first is a subconscious process while the latter, a conscious process. Krashen referred that there are two autonomous second-language performance systems, 'the acquired system' and 'the learned system'. The 'acquired scheme' or 'acquisition' is the result of a very comparable subconscious process when kids obtain their first language. It needs significant interaction in the target language which is a natural communication where the speaker focuses in the communicative act and not in the form of their utterances.

As for Monitor hypothesis, it emphasized the very limited role of 'learning' in second language performance. The 'learning' itself stands as a monitor for monitoring the language out. In order to activate the monitoring system, there are three conditions to be met such as time, emphasis on form and sufficient knowledge of the rules (Dulay \& Burt, 1978). However, Krashen categorize the learners into three; highly monitored, moderate monitored and low monitored. If the learners are highly monitored, then it leads to less production of output.

The third hypothesis, the Input hypothesis explains in order to obtain a wide variety of language input, the learners must read books, watch videos, converse with native speakers and listen to the target language. It is more concern on acquisition to get more target language atmosphere. On the other hand, the Natural-Order hypothesis recommended it is possible for an acquisition of grammatical structures follows a natural order. The fifth hypothesis which is the Affective Filter 
INTERNATIONAL JOURNAL OF ACADEMIC RESEARCH IN BUSINESS AND SOCIAL SCIENCES Vol. 10, No. 4, April, 2020, E-ISSN: 2222-6990 @ 2020 HRMARS

hypothesis. A variety of affective variables relate to success in second language acquisition. Factors that It claims that affect the learner to acquire the second language acquisition are motivation, selfconfidence and anxiety (Krashen, 1987).

A recent study by Raju and Joshith (2018) stated that the theory of Second Language Acquisition can be feasibly applied in classroom and outside the classroom which will be used in the approach of Highly Immersive Program. Developing reading habits is one of the approaches that needs teacher to be the motivator. Teacher must motivate the learners to find external reading materials such as novels, stories or poems of well-known writer or poet. Hence, ensuring the acquisition of target language input.

\section{Theory of Social Learning}

This study also applies the theory of social learning. Bandura (1971) states that new behaviour patterns can be learned in the social learning environment by direct experience or by studying others' behaviour. The more basic form of learning, ingrained in direct experiences, depends largely on the rewarding and punishing results of any action. Students will be repeatedly confronted with situations with which they must deal in one way or another. Some of the responses that they are trying to prove unsuccessful, while others have more favourable effects.

Eventually, positive modes of actions are chosen from exploratory behaviours through this method of differential reinforcement, whereas unsuccessful ones are discarded. The Highly Immersive Program creates a rich English-speaking environment where the social learning theory encompasses attention, memory and motivation of the students. Students will learn via observation, imitation and modelling.

\section{CIPP Evaluation Model}

Initially, the evaluation method was an outcome of Stufflebeam's perseverance which its goal is to help people make better decisions about their products and educational programs. This evaluation model is essential to focus on the idea of making a good decision, which is an approach to attempt to provide relevant information for those who require legitimate and unbiased evaluative information (Fitzpatrick et al. 2004).

Many strategies and models of assessment had been used to evaluate institutes, projects, programs or task. CIPP model of Stufflebeam in 1983 was a curriculum assessment model that involves four components, context, input, process and product. This model can be used efficiently to measure the quality of school education. Context are referring to goals, aims, history and background of the Program whereas input refers to material, time, physical and human resources needed for effective implementation of HIP in schools. As for the process, it includes all of the teaching and learning processes whereas product focuses on the usefulness and potentials that benefit the society on the quality of teaching learning (Stufflebeam, 2003). 
INTERNATIONAL JOURNAL OF ACADEMIC RESEARCH IN BUSINESS AND SOCIAL SCIENCES

Vol. 10, No. 4, April, 2020, E-ISSN: 2222-6990 @ 2020 HRMARS

\section{Conceptual Framework}

Figure 1. CIPP model for evaluation's conceptual framework

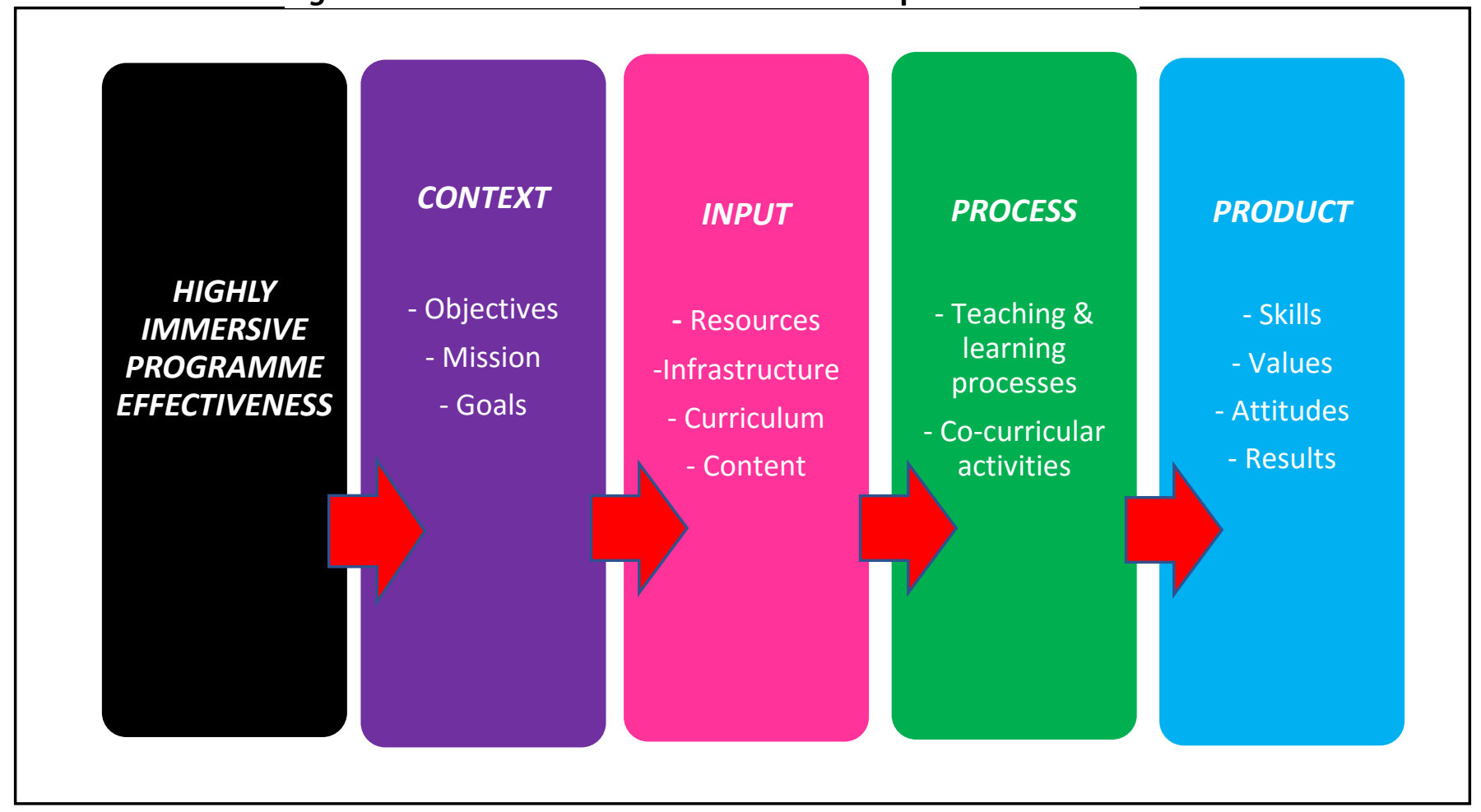

According to Figure 1, there are four proportions studied for Program evaluation at school level which is focusing on the aspects of objectives, goals and missions, including the different components of context, input, process and product. These are constructs that will determine an effective HIP Program. Context refers to the need and opportunities that defines the goals and objectives on the basis which the outcomes are attained. Input denotes the resources, organization, curriculum, and content needed to conduct the process of teaching and learning. On the other hand, process includes the processes of teaching learning, evaluation and activities which includes all the methods that are necessary for the execution of different activities and their formative evaluation. To identify the outcomes and effectiveness of the educational Program, attitudes, values, skills and results are needed as the product evaluation (Stufflebeam, 2003).

\section{Methodology}

Participants

The study was conducted in a semi-urban primary school in Bintulu, Sarawak. Every classes consist of mixed-ability students. The participants of this study are chosen purposely as the researcher wants feedback from the participants which at least with average proficiency level in English language. A total of 104 students was selected from Year 5 students by purposive sampling strategy. This study employs maximum variation sampling which is also known as "heterogenous sampling" (Etikan, Musa \& Alkassim, 2016). This method also important as it aims to select a broad spectrum reating to the topic of the study.

This was also due to students from exam classes such as Year 6 are not allowed to be included as the participants of the survey. to answer the questionnaire and their exam result will be monitored and recorded. All 52 teachers including the non-English language teacher will answer the 
INTERNATIONAL JOURNAL OF ACADEMIC RESEARCH IN BUSINESS AND SOCIAL SCIENCES Vol. 10, No. 4, April, 2020, E-ISSN: 2222-6990 @ 2020 HRMARS

questionnaires. As for the parents and community, 104 of them were picked randomly to answer the questionnaire. A total of one School Head, 52 teachers and 104 students and 104 of parents and community were answering the questionnaire adopted from both Teachers' Assessment Tool and Parent \& Community Assessment Tool from Highly Immersive Program Toolkit, respectively.

\section{Instrument}

The instrument used in this study comprises several research instruments to gather adequate and appropriate data to fulfil the research objectives and answer the research questions. A written document will be prepared to record the information of the teachers, their SPM English's grade and their years of teaching experiences. The questionnaire is adopted from HIP Toolkit Questionnaire and comprises of four types of questionnaires which are the School Head Assessment Tool, Teachers Assessment Tool, Students Assessment Tool and Parent and Community Assessment Tool. The questionnaires are rated on a five-point Likert scale.

\section{Data Analysis}

In this research, the researcher was using the Stufflebeam's Context, Input, Process and Product (CIPP) evaluation model to analyse the data collected. This study focuses on the context evaluation, input evaluation, process evaluation and product evaluation. For the first three evaluation, descriptive data is used to analyse the total score of each construct. The product evaluation is determined by performing paired sample T test on students' mid-year exam and the end of year examination paper for the English language subject which are Bahasa Inggeris Pemahaman and Bahasa Inggeris Penulisan. Secondly, the total and mean score for each group; school head, teachers, students, parents and community will be calculated. The total score determined the level of immersiveness of the Program of the school.

\section{Data Collection Procedure}

To collect the data, permission were obtained from the headmaster of the school via official letter before the data collection was carried out. Once permission was obtained, questionnaires were distributed to the students and parents, while teachers answer the questionnaires via Google Form. Prior to the distribution of the questionnaires, the questionnaire was adopted from the HIP Assessment Toolkit. And piloted with a few teachers and students from other district. This was to ensure that the questions were clear before the data collection. The questionnaires for the parents was also piloted from other schools to ensure the clarity of the questions.

This study was conducted in the form of evaluation research and the data collection procedure followed Stufflebeam (2003) CIPP model processes. As for the first step of the data collection procedures, the pre-test was introduced at the first stage of the research. The pre-test here refers to mid-year examination paper. The question papers consisted of the same components as the UPSR formatted questions.

As for the context component in CIPP evaluation model, item 1 until item 7 in the Toolkit Questionnaire indicates the vital facilities and tools to carry out the Program. The scores were collected and compared based on the table of descriptions for Level of Immersiveness. As for the input component, the documents from HIP Guidebook were used to determine whether the objectives and activities suggested in the guidebook are clear and useful.

Next, as for the process component, organisation of English activities in school such as Fun Learning and Let's Read Together (Shared/Guided Reading). The school also implemented Out-of- 
INTERNATIONAL JOURNAL OF ACADEMIC RESEARCH IN BUSINESS AND SOCIAL SCIENCES Vol. 10, No. 4, April, 2020, E-ISSN: 2222-6990 @ 2020 HRMARS

Class activities such as Assembly in English, Language Games. Little Library and Speaker's Corner. The parents' responses was collected from item 12 until item 17 of the questionnaire of Parents Assessment Tool.

Finally, the product component of the study, a post-test which is the end of year examination was conducted. Then, a paired sample T test was performed on samples' pre-test result and post-test result.

\section{Findings}

\section{Context}

Based on the CIPP evaluation model's first component which is context, the results shown in Table 1 refers to the needs of the school that define the goals and objectives of this evaluation. The school concerned indicated that it has the vital facilities and sufficient resources to carry out the Program. Items from Construct 1 focusing on creating an English environment. The questionnaire from item 1 until item 7 asked on the frequency of the students speak in English in their class, out of class and with their friends, teachers and parents as well as the community around them. These items were taken from the Students' Assessment Tool questionnaire.

Table 1 Responses from students on component of context

\begin{tabular}{|c|c|c|c|c|c|c|c|c|c|c|c|c|c|c|}
\hline \multirow{2}{*}{$\begin{array}{c}\text { Context } \\
\text { Evaluatio } \\
n\end{array}$} & \multicolumn{2}{|c|}{ Item 1} & \multicolumn{2}{|c|}{ Item 2} & \multicolumn{2}{|c|}{ Item 3} & \multicolumn{2}{|c|}{ Item 4} & \multicolumn{2}{|c|}{ Item 5} & \multicolumn{2}{|c|}{ Item 6} & \multicolumn{2}{|c|}{ Item 7} \\
\hline & $f$ & $\%$ & $f$ & $\%$ & $f$ & $\%$ & $f$ & $\%$ & $f$ & $\%$ & $f$ & $\%$ & $f$ & $\%$ \\
\hline Not at all & 7 & 6.7 & 19 & $\begin{array}{c}18 . \\
3\end{array}$ & 19 & $\begin{array}{c}18.3 \\
0\end{array}$ & 8 & 7.7 & 29 & $\begin{array}{c}27 . \\
9\end{array}$ & 38 & $\begin{array}{c}36 . \\
5\end{array}$ & 35 & $\begin{array}{c}34 . \\
6\end{array}$ \\
\hline Seldom & 35 & $\begin{array}{c}33 . \\
7\end{array}$ & 50 & $\begin{array}{c}48 . \\
1\end{array}$ & 41 & 39.4 & 32 & $\begin{array}{c}30 . \\
8\end{array}$ & 36 & $\begin{array}{c}34 . \\
6\end{array}$ & 42 & $\begin{array}{c}40 \\
4\end{array}$ & 39 & $\begin{array}{c}67 . \\
5\end{array}$ \\
\hline $\begin{array}{c}\text { Sometime } \\
\mathrm{s}\end{array}$ & 48 & $\begin{array}{c}46 . \\
2\end{array}$ & 31 & $\begin{array}{c}29 . \\
8\end{array}$ & 30 & 28.8 & 45 & $\begin{array}{c}43 . \\
3\end{array}$ & 17 & $\begin{array}{c}16 . \\
3\end{array}$ & 14 & $\begin{array}{c}13 . \\
5\end{array}$ & 23 & $\begin{array}{c}22 . \\
1\end{array}$ \\
\hline Often & 11 & $\begin{array}{c}10 . \\
6\end{array}$ & 2 & 1.9 & 12 & 11.5 & 11 & $\begin{array}{c}10 . \\
6\end{array}$ & 16 & $\begin{array}{c}15 . \\
4\end{array}$ & 8 & 7.7 & 5 & 4.8 \\
\hline $\begin{array}{l}\text { Very } \\
\text { Often }\end{array}$ & 3 & $\begin{array}{c}2.9 \\
0\end{array}$ & 2 & 1.9 & 2 & 1.9 & 8 & 7.7 & 6 & 5.8 & 2 & 1.9 & 1 & 1.0 \\
\hline TOTAL & $\begin{array}{c}10 \\
4\end{array}$ & 100 & $\begin{array}{c}10 \\
4\end{array}$ & 100 & $\begin{array}{c}10 \\
4\end{array}$ & 100 & $\begin{array}{c}10 \\
4\end{array}$ & 100 & $\begin{array}{c}10 \\
4\end{array}$ & 100 & $\begin{array}{c}10 \\
4\end{array}$ & 100 & $\begin{array}{c}10 \\
4\end{array}$ & 100 \\
\hline
\end{tabular}

Despite the fact that the school has enough facilities, these findings caused a great concern to the teachers. It shows in the next items continuation from Construct 1 (Table 2) and Construct 2 (Table 3 ) revealed that the students have difficulties in building their confidence in using English language. 
INTERNATIONAL JOURNAL OF ACADEMIC RESEARCH IN BUSINESS AND SOCIAL SCIENCES Vol. 10, No. 4, April, 2020, E-ISSN: 2222-6990 @ 2020 HRMARS

Table 2 Responses from students on component of context in Construct 1

\begin{tabular}{|c|c|c|c|c|c|c|c|c|}
\hline \multirow{2}{*}{$\begin{array}{c}\text { Context } \\
\text { Evaluation }\end{array}$} & \multicolumn{2}{|c|}{ Item 8} & \multicolumn{2}{|c|}{ Item 9} & \multicolumn{2}{|c|}{ Item 10} & \multicolumn{2}{|c|}{ Item 11} \\
\hline & $f$ & $\%$ & $f$ & $\%$ & $f$ & $\%$ & $f$ & $\%$ \\
\hline Not at all & 17 & 16.3 & 13 & 12.5 & 36 & 34.6 & 45 & 43.3 \\
\hline Seldom & 30 & 30.0 & 30 & 28.8 & 34 & 32.7 & 32 & 30.8 \\
\hline Sometimes & 34 & 34.0 & 36 & 34.6 & 17 & 16.3 & 19 & 18.3 \\
\hline Often & 19 & 19.0 & 19 & 18.3 & 9 & 8.7 & 6 & 5.8 \\
\hline Very Often & 4 & 4.0 & 6 & 5.8 & 8 & 7.7 & 2 & 1.9 \\
\hline TOTAL & 104 & 100 & 104 & 100 & 104 & 100 & 104 & 100 \\
\hline
\end{tabular}

Items from Table 2, showing that students mostly answered 'Seldom' and 'Sometimes' in questions regarding carrying out activities in English language with their friends, teachers, parents and other people around them.

Table 3 Responses from students on component of context in Construct 2

\begin{tabular}{ccccccccc}
\hline $\begin{array}{c}\text { Context } \\
\text { Evaluation }\end{array}$ & \multicolumn{2}{c}{ Item 1 } & \multicolumn{2}{c}{ Item 2 } & \multicolumn{2}{c}{ Item 3 } & \multicolumn{2}{c}{ Item 4 } \\
\hline & $f$ & $\%$ & $f$ & $\%$ & $f$ & $\%$ & $f$ & $\%$ \\
\hline Not at all & 37 & 35.6 & 44 & 42.3 & 29 & 27.9 & 32 & 30.8 \\
\cline { 2 - 11 } Seldom & 26 & 25.0 & 27 & 26.0 & 34 & 32.7 & 35 & 33.7 \\
\cline { 2 - 11 } Sometimes & 23 & 22.1 & 16 & 15.4 & 25 & 24.0 & 21 & 20.2 \\
\cline { 2 - 11 } Often & 13 & 12.5 & 14 & 13.5 & 13 & 12.5 & 12 & 11.5 \\
\cline { 2 - 11 } Very Often & 5 & 4.8 & 3 & 2.9 & 3 & 2.9 & 4 & 3.8 \\
\hline TOTAL & 104 & 100 & 104 & 100 & 104 & 100 & 104 & 100 \\
\hline
\end{tabular}

In Table 3, item 1 indicates 35.6\% students never take part in English activities in school. Based on item 2, only 16.4\% students are actively taking part in English activities in school. On the other hand, item 3 and 4 showed only $39.4 \%$ and $35.5 \%$ students respectively are interested to take part in English activities and English language competitions. It is clear that they are not interested to take part in English language activities due to lack of confidence in speaking English language. Due to the classroom size of the students in the school, which are 35 to 40 students, has a negative effect towards their psychological well-being in English language class. A study by Alivenini et al. (2019) showed that there is a negative relationship between classroom size and positive affect. It is suggested smaller classroom should be formed to promote students' psychological well-being in class. 
INTERNATIONAL JOURNAL OF ACADEMIC RESEARCH IN BUSINESS AND SOCIAL SCIENCES Vol. 10, No. 4, April, 2020, E-ISSN: 2222-6990 @ 2020 HRMARS

Table 4 Responses from students on component of context from Construct 3

\begin{tabular}{|c|c|c|c|c|c|c|c|c|c|c|}
\hline \multirow{2}{*}{$\begin{array}{c}\text { Context } \\
\text { Evaluation }\end{array}$} & \multicolumn{2}{|c|}{ Item 1} & \multicolumn{2}{|c|}{ Item 2} & \multicolumn{2}{|c|}{ Item 3} & \multicolumn{2}{|c|}{ Item 4} & \multicolumn{2}{|c|}{ Item 5} \\
\hline & $f$ & $\%$ & $f$ & $\%$ & $f$ & $\%$ & $f$ & $\%$ & $f$ & $\%$ \\
\hline Not at all & 2 & 1.9 & 5 & 4.8 & 6 & 5.8 & 19 & 18.3 & 46 & 44.2 \\
\hline Seldom & 3 & 2.9 & 26 & 25.0 & 16 & 15.4 & 14 & 13.5 & 26 & 25.0 \\
\hline Sometimes & 26 & 25.0 & 43 & 41.3 & 17 & 16.3 & 22 & 21.2 & 21 & 20.2 \\
\hline Often & 20 & 19.2 & 14 & 13.5 & 27 & 26.0 & 13 & 12.5 & 8 & 7.7 \\
\hline Very Often & 53 & 51.0 & 16 & 15.4 & 38 & 36.5 & 36 & 34.6 & 3 & 2.9 \\
\hline TOTAL & 104 & 100 & 104 & 100 & 104 & 100 & 104 & 100 & 104 & 100 \\
\hline
\end{tabular}

Contrary to the findings in Table 3, Table 4 indicates that the pupils in the school are motivated to improve their English on their own. These items are collected from Construct 3 referring to their involvement in self-development and studies. From item 1, they prefer to listen to English songs to help them to improve their English language skills rather than reading books and comics as stated in item 2. Item 3 and item 4 indicates that they also prefer to watch English movies, cartoons and videos and social medias such as Facebook and Whatsapp. Nonetheless, item 5 showed another lack of confidence in learning English indicator where more than $50 \%$ seldom and never teach their friends in learning English.

Input

Based on the document entitled HIP Guidebook, it was reviewed that the activities recommended in the guidebook are beneficial and the objectives of HIP are clear. HIP has strong objectives and it was presented thoroughly in the guidebook. The activities in the toolkit are developed based on essential parameters such as cost required for each activity, ease of implementation and other requirements of the activities. Schools may refer to the parameters and activities provided that are more suited to their current level of readiness and resources. It is not a Program that caters one size fits all. This is to ensure that the four key factors which are the School Head, teachers, students, parents and community have a clear view about the Program.

Table 5

Distribution of years of English teachers' teaching experience

\begin{tabular}{|c|c|c|}
\hline Teaching experience & Frequency & $\mathbf{\%}$ \\
\hline $1-5$ years & 3 & 27.3 \\
\hline $6-10$ years & 2 & 18.1 \\
\hline $11-15$ years & 3 & 27.3 \\
\hline $16-20$ years & 0 & 0 \\
\hline 21 years and above & 3 & 27.3 \\
\hline TOTAL & $\mathbf{1 1}$ & $\mathbf{1 0 0 . 0 0}$ \\
\hline
\end{tabular}

Significantly, to form a solid foundation, human resources were taken into account to achieve the objectives of the Program. Table 5 shows 3 teachers have 1 until 5 years of experiences in teaching English language whereas 2 teachers have 6 to 10 years of experiences, 3 teachers have 11 to 15 
INTERNATIONAL JOURNAL OF ACADEMIC RESEARCH IN BUSINESS AND SOCIAL SCIENCES

Vol. 10, No. 4, April, 2020, E-ISSN: 2222-6990 @ 2020 HRMARS

years of experiences and another 3 teachers have 21 years and above of experiences in teaching the language.

\section{Process}

To evaluate the process, researcher studied the English activities that have been implemented under HIP. Activities that were done in the school such as In-Class activities. For example, Let's Read Together (Shared/Guided Reading) and Fun Learning. The school also implemented Out-of-Class activities such as Assembly in English, Language Games, Little Library and Speaker's Corner.

Table $6 \quad$ Parents' responses on process component

\begin{tabular}{|c|c|c|c|c|c|c|c|c|c|c|c|c|}
\hline \multirow{2}{*}{$\begin{array}{c}\text { Process } \\
\text { Evaluation }\end{array}$} & \multicolumn{2}{|c|}{ Item 12} & \multicolumn{2}{|c|}{ Item 13} & \multicolumn{2}{|c|}{ Item 14} & \multicolumn{2}{|c|}{ Item 15} & \multicolumn{2}{|c|}{ Item 16} & \multicolumn{2}{|c|}{ Item 17} \\
\hline & $f$ & $\%$ & $f$ & $\%$ & $f$ & $\%$ & $f$ & $\%$ & $f$ & $\%$ & $f$ & $\%$ \\
\hline Not at all & 11 & 10.6 & 25 & 24.0 & 32 & 30.8 & 4 & 3.8 & 0 & 0 & 3 & 2.9 \\
\hline Seldom & 80 & 76.9 & 66 & 63.5 & 64 & 61.5 & 94 & 90.4 & 2 & 1.9 & 1 & 1.0 \\
\hline Sometimes & 12 & 11.5 & 13 & 12.5 & 7 & 6.7 & 5 & 4.8 & 2 & 1.9 & 97 & 93.3 \\
\hline Often & 1 & 1.0 & 0 & 0 & 1 & 1.0 & 1 & 1.0 & 99 & 95.2 & 3 & 2.9 \\
\hline Very Often & 0 & 0 & 0 & 0 & 0 & 0 & 0 & 0 & 1 & 1.0 & 0 & 3 \\
\hline TOTAL & 104 & 100 & 104 & 100 & 104 & 100 & 104 & 100 & 104 & 100 & 104 & 100 \\
\hline
\end{tabular}

The above data Table 6, which are items numbered 12 until 17 indicates the support from parents and community along the HIP implementation. The support refers to organising English language activities, coaching the students in English language activities and competition, sharing ideas related to English language activities with teachers in the school and preparing English materials for the students.

\section{Product}

\section{Paired Sample T test for Bahasa Inggeris Pemahaman}

A paired sample T test was performed on students' mid-semester examination (pre-test) and their end of year examination (post-test) results of two English language papers which are for the subject Bahasa Inggeris Pemahaman and Bahasa Inggeris Penulisan. The number of students participated in the study is 104.

Table $7 \quad$ Paired sample T test of students Bahasa Inggeris Pemahaman paper

\begin{tabular}{|c|c|c|c|c|c|}
\hline & & Mean & $\mathrm{N}$ & $\begin{array}{l}\text { Std. } \\
\text { Deviation }\end{array}$ & $\begin{array}{l}\text { Std. Error } \\
\text { Mean }\end{array}$ \\
\hline Pair 1 & $\begin{array}{l}\text { Pre-test } \\
\text { Post- } \\
\text { test }\end{array}$ & $\begin{array}{l}53.69 \\
44.79\end{array}$ & $\begin{array}{l}104 \\
104\end{array}$ & $\begin{array}{l}17.204 \\
17.743\end{array}$ & $\begin{array}{l}1.687 \\
1.740\end{array}$ \\
\hline
\end{tabular}

Table 7 shows the mean scores and standard values of the students, while Table 8 shows the significant value. For Bahasa Inggeris Pemahaman, students' mean score for pre-test is 53.69 while for post-test is 44.79. The standard deviation for pre-test and post-test is 17.204 and 17.743 
INTERNATIONAL JOURNAL OF ACADEMIC RESEARCH IN BUSINESS AND SOCIAL SCIENCES Vol. 10, No. 4, April, 2020, E-ISSN: 2222-6990 @ 2020 HRMARS

respectively. The mean score for the post-test is lesser than the mean score in pre-test. This indicated the students performed better in pre-test than post-test. Hence, this is likely due to the inconsistency of the implementation of HIP throughout the year.

Table 8

Paired sample T test of students Bahasa Inggeris Pemahaman paper

\begin{tabular}{|c|c|c|c|c|c|c|c|c|}
\hline & \multicolumn{5}{|c|}{ Paired Differences } & \multirow[b]{3}{*}{$\mathrm{t}$} & \multirow[b]{3}{*}{$\mathrm{df}$} & \multirow{3}{*}{$\begin{array}{l}\text { Sig. (2- } \\
\text { tailed) }\end{array}$} \\
\hline & \multirow{2}{*}{$\begin{array}{c}\text { Mea } \\
\mathrm{n}\end{array}$} & \multirow{2}{*}{\begin{tabular}{|c|} 
Std. \\
Deviatio \\
$\mathrm{n}$
\end{tabular}} & \multirow{2}{*}{$\begin{array}{l}\text { Std. } \\
\text { Error } \\
\text { Mean }\end{array}$} & \multicolumn{2}{|c|}{$\begin{array}{c}95 \% \text { Confidence } \\
\text { Interval of the } \\
\text { Difference }\end{array}$} & & & \\
\hline & & & & Lower & Upper & & & \\
\hline $\begin{array}{ll}\text { Pair } & \text { Pre-test - } \\
1 & \text { Post-test }\end{array}$ & $\begin{array}{r}8.90 \\
4\end{array}$ & 10.922 & 1.071 & 6.780 & 11.028 & $\begin{array}{r}8.31 \\
4\end{array}$ & 103 & .000 \\
\hline
\end{tabular}

The result from Table 8 gives the sig.(2-tailed) value is 0.000 , which is less than 0.05 .

\section{Paired Sample T test for Bahasa Inggeris Penulisan}

Table 9

Paired sample T test of students Bahasa Inggeris Penulisan paper

\begin{tabular}{|ll|r|r|r|r|}
\hline & & Mean & N & Std. Deviation & Std. Error Mean \\
\hline Pair 1 & pretest & 38.29 & 104 & 17.831 & 1.748 \\
& posttest & 39.92 & 104 & 15.242 & 1.495 \\
\hline
\end{tabular}

As for another paper, Bahasa Inggeris Penulisan, the mean score for the post-test is 39.92 whereas the mean score for the pre-test is 38.29. The standard deviation for pre-test and post-test is 17.831 and 15.242 respectively. Since the mean score for this post-test was greater than the mean score for pre-test, we can conclude that students performed slightly better in post-test than the pretest.

Table 10

Paired sample T test of students Bahasa Inggeris Penulisan paper

\begin{tabular}{|c|c|c|c|c|c|c|c|c|}
\hline & \multicolumn{5}{|c|}{ Paired Differences } & \multirow[b]{3}{*}{$\mathrm{t}$} & \multirow[b]{3}{*}{$\mathrm{df}$} & \multirow{3}{*}{$\begin{array}{l}\text { Sig. (2- } \\
\text { tailed) }\end{array}$} \\
\hline & \multirow[b]{2}{*}{ Mean } & \multirow{2}{*}{$\begin{array}{c}\text { Std. } \\
\text { Deviatio } \\
n\end{array}$} & \multirow{2}{*}{$\begin{array}{l}\text { Std. } \\
\text { Error } \\
\text { Mean }\end{array}$} & \multicolumn{2}{|c|}{$\begin{array}{c}95 \% \text { Confidence } \\
\text { Interval of the } \\
\text { Difference }\end{array}$} & & & \\
\hline & & & & Lower & Upper & & & \\
\hline $\begin{array}{ll}\text { Pair } & \text { pretest - } \\
1 & \text { posttest }\end{array}$ & $\begin{array}{r}- \\
1.635\end{array}$ & 11.820 & 1.159 & -3.933 & .664 & $1.410^{-}$ & 103 & .161 \\
\hline
\end{tabular}

Table 10 shows the significant value for the pre-test and post-test of Bahasa Inggeris Penulisan paper, gives the sig.(2-tailed) value is 0.161 , which is greater than 0.05 . 
INTERNATIONAL JOURNAL OF ACADEMIC RESEARCH IN BUSINESS AND SOCIAL SCIENCES

Vol. 10, No. 4, April, 2020, E-ISSN: 2222-6990 @ 2020 HRMARS

Table 11 Total school score and level of immersiveness

\begin{tabular}{|c|c|}
\hline Group & $\begin{array}{c}\text { Mean } \\
\text { score }\end{array}$ \\
\hline School Head & 47.0 \\
\hline Teachers & 44.9 \\
\hline Students & 31.20 \\
\hline $\begin{array}{c}\text { Parents and } \\
\text { Community }\end{array}$ & 37.96 \\
\hline Total score & 161.06 \\
\hline $\begin{array}{c}\text { LEVEL OF } \\
\text { IMMERSIVENESS }\end{array}$ & Level 3 \\
\hline
\end{tabular}

Apart from conducting paired sample $T$ test, in order to observe the product component of the evaluation, a total school score was calculated to determine the level of the immersiveness of the Program in the school. Table 11 shows that the level of the immersiveness at the school is Level 3. This shows that the students are in a good and meaningful English immersive environment as the school community engages them.

Students are provided with some challenging and enjoyable learning experiences. This level of immersiveness also shows that many students have the opportunity to participate in English language activities both in and out of class. As a matter of fact, the head of the school manages to create an interactive English environment. There is evidence of the sustainability of some activities of the ELT. Teachers tend to introduce students to both in - and out-of-class English language learning activities; however, this may not vary in terms of enrichment and remedial exercises. However, the activities used are only sometimes capable of boosting students ' confidence in the use of English occasionally. This is due to teachers and students do not communicate in English frequently. Nevertheless, there is some evidence of the school's participation in outreach Programs by students, collaboration with ELT experts from higher learning institutions and corporate bodies. Parents ' participation is sometimes seen in supporting the school in the ELT activities. 
INTERNATIONAL JOURNAL OF ACADEMIC RESEARCH IN BUSINESS AND SOCIAL SCIENCES

Vol. 10, No. 4, April, 2020, E-ISSN: 2222-6990 (C) 2020 HRMARS

Table 12: Summary of the Highly Immersive Program evaluation by CIPP model

\begin{tabular}{|c|c|c|c|c|}
\hline & CONTEXT & INPUT & PROCESS & PRODUCT \\
\hline Objective & $\begin{array}{c}\text { To define the content and objectives } \\
\text { of the Program }\end{array}$ & $\begin{array}{l}\text { To check the } \\
\text { teacher's } \\
\text { educational } \\
\text { background } \\
\text { and teaching } \\
\text { experiences } \\
\text { in meeting } \\
\text { the Program } \\
\text { objectives. }\end{array}$ & $\begin{array}{l}\text { To provide feedback on } \\
\text { the extent of the } \\
\text { implementation }\end{array}$ & $\begin{array}{c}\text { To collect descriptions } \\
\text { judgements of } \\
\text { outcomes }\end{array}$ \\
\hline $\begin{array}{l}\text { Method / } \\
\text { Data }\end{array}$ & $\begin{array}{l}\text { i. By conducting questionnaires. } \\
\text { ii. Item } 1 \text { until item } 7 \text { were } \\
\text { selected to measure the } \\
\text { richness of English } \\
\text { environment in the school. }\end{array}$ & $\begin{array}{l}\text { By using } \\
\text { document } \\
\text { review. }\end{array}$ & $\begin{array}{l}\text { i. By conduction } \\
\text { questionnaire. Item } \\
12 \text { until item } 17 \\
\text { were selected to } \\
\text { measure parents' } \\
\text { responses towards } \\
\text { the Program in } \\
\text { school. }\end{array}$ & $\begin{array}{l}\text { i. } \text { By performing } \\
\text { quantitative } \\
\text { analysis through } \\
\text { descriptive statistic. }\end{array}$ \\
\hline Results & $\begin{array}{l}\text { i. Average score of rich English } \\
\text { environment. } \\
\text { ii. Lack of students' confidence in } \\
\text { using English. }\end{array}$ & $\begin{array}{l}\text { i. The } \\
\text { objectives } \\
\text { of the } \\
\text { Program } \\
\text { are clear } \\
\text { and the } \\
\text { activities } \\
\text { are useful. } \\
\text { ii. There are } \\
6 \text { teachers } \\
\text { with the } \\
\text { experiences } \\
\text { of more } \\
\text { than } 10 \\
\text { years. }\end{array}$ & $\begin{array}{l}\text { The parents and } \\
\text { community were less } \\
\text { supportive towards HIP. }\end{array}$ & $\begin{array}{l}\text { i. The immersiveness } \\
\text { level of the school } \\
\text { is } 3 . \\
\text { ii. Parents give } \\
\text { positive responses } \\
\text { based on the data } \\
\text { of the interview } \\
\text { but lack of support } \\
\text { in terms of } \\
\text { materials and } \\
\text { direct involvement } \\
\text { with school. }\end{array}$ \\
\hline
\end{tabular}

Discussion, Implications and Recommendations

\section{Discussion}

The findings cover 4 main research questions which will now be discussed in reference to the research questions and literature reviewed.

\section{Research Question 1}

How relevant were the Program contents of HIP?

The findings indicated that the contents of HIP are relevant as the activities provided in the toolkit are developed based on the essential parameters such as cost required for each activity and ease of implementation of the activities. School could explore the parameters and decide activities that are more suited to their current level of their readiness and based on materials provided in school.

\section{Research Question 2}

How effective were the HIP in school? 
INTERNATIONAL JOURNAL OF ACADEMIC RESEARCH IN BUSINESS AND SOCIAL SCIENCES Vol. 10, No. 4, April, 2020, E-ISSN: 2222-6990 @ 2020 HRMARS

The HIP Program indeed was an effective Program to improve pupils' English communication proficiency. This was shown by a previous study done by Ansawi (2017) concluded that the student's achievement in the post-test is significantly higher than their achievement in the pre-test. The pretest score was $44.80 \%$ which is lower compared to the post-test mean score of $54.80 \%$. The paired sample t-test at $95 \%$ confidence level shows that the $t$ value is -4.277 at a significance level of 0.002 .

A major concern as the study indicates the level of immersiveness of the school which is Level 3 with the score of 161.06 . The score was actually 1 point ahead from the Level 2's score which is 160. This indicates the performance of the school is most likely fell close to Level 2 but slightly higher. Many reasons could be the factors that influenced the level score.

It can be seen in the results from the Parents \& Community Assessment Tool, shows that lack of direct involvement in school activities. The finding shows that the parents are not very supportive towards their children's activity. This is due to the low socioeconomic background of the parents that forced them to work at odd hours and seldom spend their time with their children. The low-income level of the parents also affected the way they spend their money. This constraint does not allow them to provide good materials and resources to have a rich environment of English for their children at home.

\section{Research Question 3}

\section{What is the process of HIP?}

The process of HIP is determined by collecting data based on items referred from two questionnaires from School Head Assessment Tool and Teachers Assessment Tool. As for School Head Assessment Tool, Construct 2 refers to their role as a leader and constant motivator whereas Construct 3 refers to their role to ensure the sustainability of HIP implementation in the school. This includes ensuring the senior assistants and teachers are committed in implementing English activities. The School Head also must ensure he or she allocates sufficient funds to promote English in schools through materials such as posters, signages, newspapers and other materials. On the same time, the School Head also must make sure the school has various facilities to support the teaching and learning of English. On the other hand, Construct 4 refers to their role in encouraging the parents and community to participate in English activities in school.

\section{Research Question 4}

\section{What is the product of HIP?}

The product of HIP can be observed from the results of mid-year examination and end of year examination from both subjects of Bahasa Inggeris Pemahaman and Bahasa Inggeris Penulisan. From the study, the students performed better in pre-test than post-test for their Bahasa Inggeris Pemahaman. On the other hand, for Bahasa Inggeris Penulisan, students performed slightly better in post-test than the pre-test. Hence, this is likely due to the inconsistency of the implementation of HIP throughout the year. The performance of the students is the chain reaction from the process implemented by School Head, teachers, parents and community.

The inconsistency may be due to the class size, where a class will have up to 40 students. A study revealed that due to the class size, it has caused a negative effect towards students' psychological well-being in English language class. As promoted by Alivernini et al. (2019), smaller classroom should be formed to have students' motivation increased.

In a study done by Jiew (2017), due to passive participation in supporting school activities by parents, it affected their children and their children seldom communicate in English when they are 
INTERNATIONAL JOURNAL OF ACADEMIC RESEARCH IN BUSINESS AND SOCIAL SCIENCES Vol. 10, No. 4, April, 2020, E-ISSN: 2222-6990 @ 2020 HRMARS

out of school's perimeter. Due to that, a consistent pace of monitoring of the Program is essential so that the students, parents and community can participate so that effective activities can be conducted along the HIP. Their involvement in the process affects how the students build their confidence to use English and involvement in their self-development and studies.

\section{Conclusion}

The main conclusion that can be drawn is that the CIPP evaluation model had helped the researchers to explore further on how immersive the Program was. The results revealed the level of immersiveness of the school studied was Level 3. It was also observed that the School Head and teachers acknowledged reflections are important part to improve the implementation of HIP. This evaluation also provided insights data to the teacher to create new effective activities based on the context of the school. It also provided abundance of opportunities to students to expose themselves to rich English language environment. Our data indicated that the students were also aware that they are lacking confidence which led to lack of interest in learning English language. On the other hand, parents and community gave positive responses through the questionnaire but in terms of support and direct involvement they were disinclined. As for the limitation, the participants of the study only subjected to activities that is relevant to the school studied. The sample size of the study may not imply the characteristics of the entire population.

\section{Recommendation}

Based on the major findings, interesting research question for future research can be derived. For example, what are the factors could affect the motivation of the student's before and after the implementation of HIP? Future research could further investigate by developing questionnaire based on the theories of Second Language Acquisition, particularly, the Affective Filter Hypotheses. This can be included under the aspect of process in the CIPP model evaluation. Therefore, the teachers may reflect on the factors of student's motivation and improvise their teaching skills accordingly. It is also crucial to put more efforts to encourage the parents and the community to participate in the Program. The researchers believe that extensive involvement of the parents and community plays a vital role in boosting the students' motivation. It will be more fruitful, if the policy planners develop a standardized module based on the readiness and immersiveness of school after an evaluation. Hence, it will be easier to identify areas that need to be improve and provide a solid foundation for the school to have an English-rich environment. Above all, it requires a full commitment within the school community to enrich the students' proficiency in English language and encourages a meaningful learning.

\section{References}

Alivernini, F., Cavicchiolo, E., Manganelli, S., Chirico, A., \& Lucidi, F. (2019). Students' psychological well-being and its multilevel relationship with immigrant background, gender, socioeconomic status, achievement, and class size. School Effectiveness and and School Improvement, International Journal of Research, Policy and Practice. https://doi.org/10.1080/09243453.2019.1642214

Ansawi, B. (2017). Promoting the 3Es (Exposure, Experience, Engagement) in an English-Rich Rural Primary School Community, The English Teacher, 46(1), 30-42.

Bandura, A. (1971). Social Learning Theory. General Learning Press. 
INTERNATIONAL JOURNAL OF ACADEMIC RESEARCH IN BUSINESS AND SOCIAL SCIENCES

Vol. 10, No. 4, April, 2020, E-ISSN: 2222-6990 @ 2020 HRMARS

Brown, J. D. (1989). Language program evaluation: A synthesis of existing possibilities. The second language curriculum. Cambridge University Press.

Dulay, H. C., \& Burt, M. K. (1978). Second language acquisition research: Issues \& implications. New York: Academic Press.

Etikan, I., Musa, S. A., \& Alkassim, R. S. (2016). Comparison of Convenience Sampling and Purposive Sampling. American Journal of Theoretical and Applied Statistics. 5(1),1-4. https://doi.org/10.11648/j.ajtas.20160501.11

Fitzpatrick, J. L., Sanders, J. R., \& Worthen, B. R. (2004). Program evaluation: Alternative approaches and practical guideline ( $3^{\text {rd }}$ ed.). Pearson.

Government of Malaysia. (1996). Laws of Malaysia. Education Act 1996 (Act 550). Government of Malaysia.

Jiew, F. F. (2017). The Evaluation of Highly Immersive Program (HIP). International Journal of Academics in Business and Social Sciences. 7(2), 437-449. http://dx.doi.org/10.6007/IJARBSS/v7-i2/2652

Karmel, L. J., \& Karmel, M. O. (1978). Measurement and evaluation in schools (2 ${ }^{\text {nd }}$ ed.). Macmillan Publishing.

Kellaghan, T., \& Stufflebeam, D. L. (2003). International Handbook of Educational Evaluation. Kluwer Academic Publishers. https://doi.org/10.1007/978-94-010-0309-4

Krashen, S. (1982). Principles and practice in second language acquisition. Pergamon Press Inc.

Krashen, S. D. (1987). Principles and practice in second language acquisition. Prentice-Hall International.

Krashen, S. D. (1988). Second Language Acquisition and Second Language Learning. Prentice Hall International.

Ministry of Education Malaysia. (2012). National Education Policy ( $3^{\text {rd }}$ Ed). Ministry of Education Malaysia.

Ministry of Education Malaysia. (2013). Malaysia Education Blueprint 2013-2025 (Preschool to PostSecondary Education). Ministry of Education Malaysia.

Raju, N., \& Joshith, V. P. (2018). Krashen's Theory of Second Language Acquisition: A Practical Approach for English Language Classrooms. International Journal of Innovative Knowledge Concepts. 6(12), 179-184.

Ornstein, A. C., \& Hunkins, F. P. (1998). Curriculum: Foundations, principles, and issues (3rd ed.). Allyn \& Bacon.

Stufflebeam, D. L. (1983) The CIPP Model for program evaluation. In Madaus, G.F., Scriven, M.S. \&

Stufflebeam, D. I. (Eds.), Evaluation models: Viewpoints on Educational and Human Services Evaluation (117-141) Kluwer-Nijhoff Publishing. https://doi.org/10.1007/978-94-009-66697_7. 